\title{
Effect of type traits on functional longevity of Czech Holstein cows estimated from a Cox proportional hazards model
}

\author{
L. Zavadilová, ${ }^{1}$ E. Němcová, and M. Štípková \\ Institute of Animal Science, Prátelství 815, 10400 Prague-Uhříněves, Czech Republic
}

\section{ABSTRACT}

Relationships between conformation traits and functional longevity in Holstein cows were evaluated using survival analysis. Functional longevity was defined as the number of days between the first calving and culling; that is, length of productive life. The data set consisted of 116,369 Holstein cows that first calved from 2003 to 2008. All cows used in the analysis were scored for conformation between d 30 and d 210 of their first lactation. The data included $48 \%$ censored records. Analyses were done separately for 20 linear descriptive type traits, 6 composite traits, and height at sacrum measured in centimeters. Cox proportional hazard models were fitted to analyze data. The hazard function was described as the product of a baseline hazard function and the time-independent effects of age at first calving and sire (random), and the timedependent effects of stage of lactation and lactation number, herd, year and season, herd size, and 305-d milk production. The strongest relationship between a composite trait and functional longevity was for dairy form, followed by udder and final score. Among the descriptive type traits, the strongest relationships with longevity were found for body condition score, angularity, traits related to udder attachment, and udder depth. Foot and leg traits showed substantially lower effect on functional longevity, and the effect of foot angle was minimal. Functional longevity declined with decreased body condition score of cows. Cows with deep udders had significantly lower functional survival compared with cows with shallow udders. In addition, weak central ligament was associated with significant reduction of cow longevity. For dairy form and angularity, cows classified as very good were the worst with respect to longevity, whereas cows classified as poor were the best. An intermediate optimum was evident for rear legs rear view and rear legs set (side view), whereas cows with sickled legs had lower longevity than cows with straighter legs.

Key words: type trait, longevity, survival analysis

Received August 4, 2010.

Accepted April 16, 2011.

${ }^{1}$ Corresponding author: zavadilova.ludmila@vuzv.cz

\section{INTRODUCTION}

The relationship between type traits and longevity in dairy cattle has been examined on numerous occasions; using different approaches, authors have shown that some traits are significantly related to longevity (Short and Lawlor, 1992; Larroque and Ducrocq, 2001; Schneider et al., 2003; Sewalem et al., 2004). Conformation traits represent logical predictors of survival (Vollema and Groen, 1997; Vukasinovic et al., 2002). When they are assessed during the first lactation, conformation traits can increase the accuracy of genetic evaluation for dairy sires (Weigel et al., 1998; Vukasinovic et al., 2002) by combining information from these correlated traits with information regarding actual time of death or culling, without waiting until a large percentage of daughters have been culled. Moreover, type traits are more highly heritable than longevity itself (Schaeffer et al., 1985; Meyer et al., 1987; Wiggans et al., 2004). The effect of type traits on functional longevity depends also on selection, culling decisions, and involuntary culling used in a particular cattle population.

In many breeds and many countries, linear scoring of type traits is carried out routinely for the total population of cows or for daughter groups of test bulls. One reason for characterizing offspring morphologically is to predict the type of cow that the breeder might expect when using semen of a particular sire. Another reason is to detect obvious deficiencies in body conformation that could result in severe health and management problems.

Analysis of longevity records using traditional linear models may not be appropriate because of the skewed distribution of longevity records and the bias caused by excluding the records of living cows or of assuming their records to be complete. Some factors that affect an animal's longevity may change throughout its lifetime, physical environment, management conditions, and milk production, for example. For these reasons, time-dependent explanatory variables should be accounted for in analyses. A method based on survival analysis has been proposed for the analysis of longevity (Smith and Quaas, 1984; Ducrocq, 1987, 1997). Survival analysis using a proportional hazards model can offer a better fit to survival data because it properly accounts 
for censored records and for the skewed distribution of survival data and can efficiently handle time-dependent explanatory variables.

Ducrocq and Sölkner (1998) developed a computer package (the Survival Kit) for survival analysis that is suitable for animal breeding data. This package has greatly facilitated the estimation of environmental effects and variance components and genetic evaluation of animals. In the Czech Republic, the official genetic evaluation for longevity is carried out using survival analysis. Documenting relationships between type traits and longevity is the required first move to combined genetic evaluation of functional longevity based on direct longevity records and information from type traits.

The objective of this study was to evaluate the relationship to functional longevity in Czech Holstein cows of conformation traits reflecting udder, feet and legs, and body size using a Cox proportional hazard model.

\section{MATERIALS AND METHODS}

\section{Data}

The data set consisted of 116,369 Holstein cows that first calved from 2003 to 2008. All cows used in the analysis were scored for conformation between $\mathrm{d} 30$ and d 210 of their first lactation. Cows were required to have valid sire identification and age at first calving between 500 and 1,200 d of age. Data were obtained from the Holstein Cattle Breeders Association of the Czech Republic. The following type traits were used. Linear type traits were fore udder attachment, rear udder height, udder depth, rear udder width, central ligament, teat length, front teat placement, rear teat position, stature, angularity, chest width, body depth, rump angle, rump width, rear legs rear view, rear legs set (side view), foot angle, bone quality, BCS, and locomotion. The traits were scored on a 9-point scale. Height at sacrum was measured in centimeters. The composite traits, evaluated in the interval between 50 and 100 points, were dairy form, body capacity, body composition, udder, final score, and feet and legs. All of the composite traits except final score were computed as a function of scores of the appropriate sets of linear type traits. Final score was computed from the other composite traits (Holstein Cattle Breeders Association of the Czech Republic, 2010). All traits were recorded on all cows, with the exceptions of locomotion (101,924 records), rear udder width (102,512 records), BCS (75,006 records), and height at sacrum (107, 935 records). Descriptions of scores of analyzed traits are shown in Table 1.

Longevity expressed as the number of days between the first calving and culling; that is, length of productive life, averaged $754 \mathrm{~d}$, with a minimum of $27 \mathrm{~d}$ and a maximum of 2,065 d. Cows that were sold for dairy purposes were considered censored, as were cows in herds that discontinued milk recording and cows that were still alive at the time of evaluation. In total, $56,149(48 \%)$ right-censored records were included in analysis. Because voluntary culling for low production is an important reason for disposal, the current analysis was based on functional survival. Functional survival was defined as the ability to delay involuntary culling, and it was approximated by correcting true longevity for within-herd-year-parity milk production ranking (see the forthcoming model explanation).

Special analyses were done for BCS. First, the effect of BCS was estimated on both functional and true longevity. Thus, in the model dealing with true longevity, no correction on milk production was used. The aim was to prove the different effect of BCS on functional and true longevity. Second, the effect of BCS was estimated on functional longevity together with angularity for assessing the relationship between these traits.

\section{Model}

Survival analysis was performed using the Survival Kit, version 3.0, by Ducrocq and Sölkner (1998). A Cox proportional hazard model was employed. Length of productive life was the dependent variable. The following model equation was used:

$$
\lambda(t)=\lambda_{0}(t) \times \exp \left\{x^{\prime}(t) \boldsymbol{\beta}+z^{\prime}(t) \boldsymbol{\sigma}\right\},
$$

where $\lambda(t)$ is the hazard of a cow; that is, her probability of being culled at time $t$ given that she is alive just before $t ; \lambda_{0}(t)$ is the baseline hazard function that represents the aging process of the whole population and, loosely speaking, acts like a mean; $t$ is the time in days from the first calving to culling; that is, length of productive life; $\boldsymbol{\beta}$ is a vector of regression coefficients for fixed effects; and $\boldsymbol{\sigma}$ is the vector of regression coefficients for the random effect. They contain the possibly time-dependent covariates affecting the hazard, with $x^{\prime}(t)$ and $z^{\prime}(t)$ being the corresponding design vectors for fixed and random effects, respectively. The Cox model permits the estimation of the regression coefficients in $\boldsymbol{\beta}$ without making any assumption about the form of the baseline hazard function $\lambda_{0}(t)$. It is possible to leave $\lambda_{0}(t)$ completely arbitrary.

The fixed covariates included in the model were as follows:

- time-independent effect of age of first calving (d), treated as a continuous covariate with linear and quadratic regression coefficients; 
Table 1. Means and standard deviations of linear type traits and their description, and of height at the sacrum, composite traits, and longevity (censored and uncensored records)

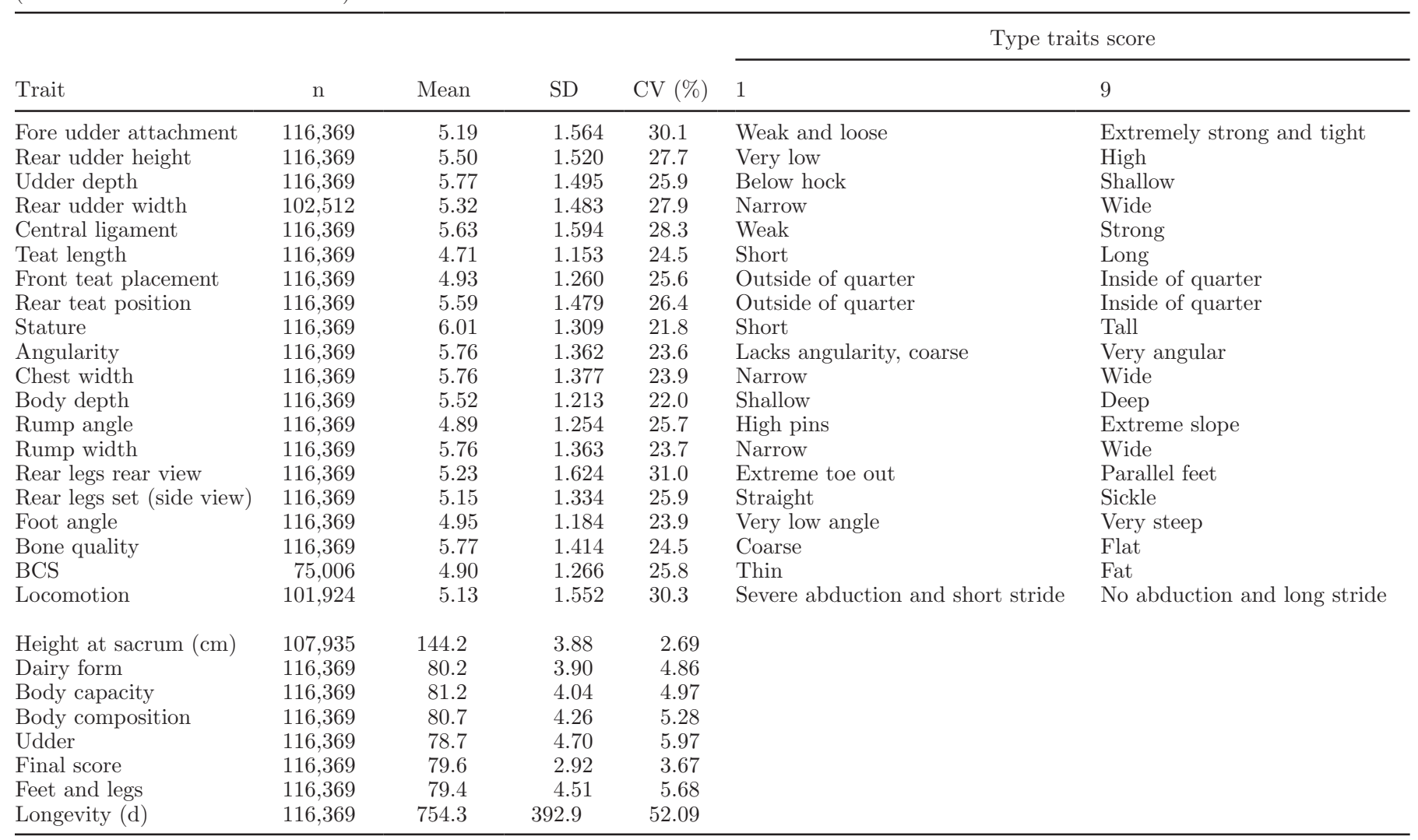

- combined time-dependent effect of lactation number $(1,2,3,4,5)$ and stage of lactation $(\mathrm{d} ; 1=$ $0-120,2=121-240,3=>240$ );

- time-dependent effect of herd, 1,185 herds;

- combined time-dependent fixed effect of year (2004-2009) and season (mo; $1=1-3,2=4-6,3$ $=7-9,4=10-12)$;

- time-dependent effect of herd size (cows; $1=<21$, $2=21-50,3=51-100,4=101-200,5=201-400$, $6=>400$ ), with changes on January 1 each year;

- time-dependent effect of lactation milk yield calculated within herd-year-parity class $(1=$ between the herd-year average and $+0.5 \mathrm{SD}, 2=$ between $+0.5 \mathrm{SD}$ and $+1 \mathrm{SD}, 3=>+1 \mathrm{SD}, 4=$ between the herd-year average and $-0.5 \mathrm{SD}, 5=$ between $-0.5 \mathrm{SD}$ and $-1 \mathrm{SD}, 6=<-1 \mathrm{SD} ; 7=$ production below $1,000 \mathrm{~kg}$ of milk per lactation and/or length of lactation $<240 \mathrm{~d}$ ) with changes at the beginning of a new lactation. Parity was defined in 2 classes: first parity and second and later parities;

- time-independent fixed effect of a particular type trait (9 points of score), composite trait (5 classes), and height at sacrum (6 levels). The detailed descriptions of the levels defined for analyzed conformation traits are provided in Tables 2 to 6 ;

The random covariate was represented by

- time-independent random effect of the sire of a cow assumed to be distributed as multivariate normal with mean 0 and covariance matrix $\mathbf{A} \sigma^{2}$, where $\mathbf{A}$ is the additive relationship matrix between sires. Only sires with at least 2 daughters were considered in the analyses. The variance of sires was 0.077 , estimated in the national genetic evaluation of longevity (Plemdat, 2010).

Analysis was done separately for each of 27 type traits. Each type trait was evaluated by including it as a class effect in the model. The relative culling risk was calculated for animals in each class after accounting for the previously mentioned effects. The relationships between functional longevity with levels of composite as well as linear type traits were expressed as the relative risk of culling (RRC), defined as the ratio of the estimated risk of being culled under the influence of certain environmental factors relative to the reference 
risk, which is set to 1 . Reference risk is presented as reference level, the level with the largest number of uncensored records. Thus, RRC values $>1$ indicate a higher culling risk associated with a given environmental factor, and RRC $<1$ indicate a lower culling risk. The relationship between longevity and some type traits seemed to be linear, but other traits are likely to have intermediate optima, with increased culling risk when type scores deviate from this optimum.

For the definition of levels of significance for RRC, we used the asymptotic standard errors of estimates of the regression coefficients and the resulting $\chi^{2}$ statistic for a Wald test of each particular regression coefficient $\boldsymbol{\beta}_{\mathrm{i}}$. In Tables 2 through 6 , we present RRC and $\chi^{2}$ statistic for the level of significance. The level of significance refers to the test if the estimated effects are different from zero. The test of significance is not calculated directly for RRC but for the estimates of the regression coefficients.

\section{RESULTS AND DISCUSSION}

\section{Relative Contribution of Each Trait}

Figure 1 shows the relative contribution of each conformation type trait to the survival likelihood. This was determined by comparing the full model (with each particular conformation trait) with the reduced model (without any conformation trait). All of the conformation traits had a statistically significant relationship with longevity $(P<0.01)$. The trait with the greatest effect on longevity was BCS. Its relative contribution to likelihood was 3 times higher than that of dairy form. Because of the large difference between these 2 most important traits (BCS and dairy form) and the substantially lower number of records for BCS $(75,006$ records) than for all other traits, BCS was not included in Figure 1.

As shown in Figure 1, other than for BCS, dairy form was by far the most important trait predictive of longevity, followed by udder and final score among the composite traits and udder depth and angularity among the linear type traits. Height at sacrum $(\mathrm{cm})$ also showed a high relative contribution. A rather small effect on cow survival was found for feet and legs (composite traits) and foot angle. The traits connected with udder attachment; that is, central ligament and fore udder attachment, showed slightly higher effects on longevity than rear legs rear view or rear legs set (side view), traits describing conformation of legs. Among foot and leg traits, the most important effect on functional survival was found for locomotion, almost at the level of central ligament.

The highest contribution to survival likelihood due to final score and mammary system was reported by Caraviello et al. (2003), Schneider et al. (2003), and

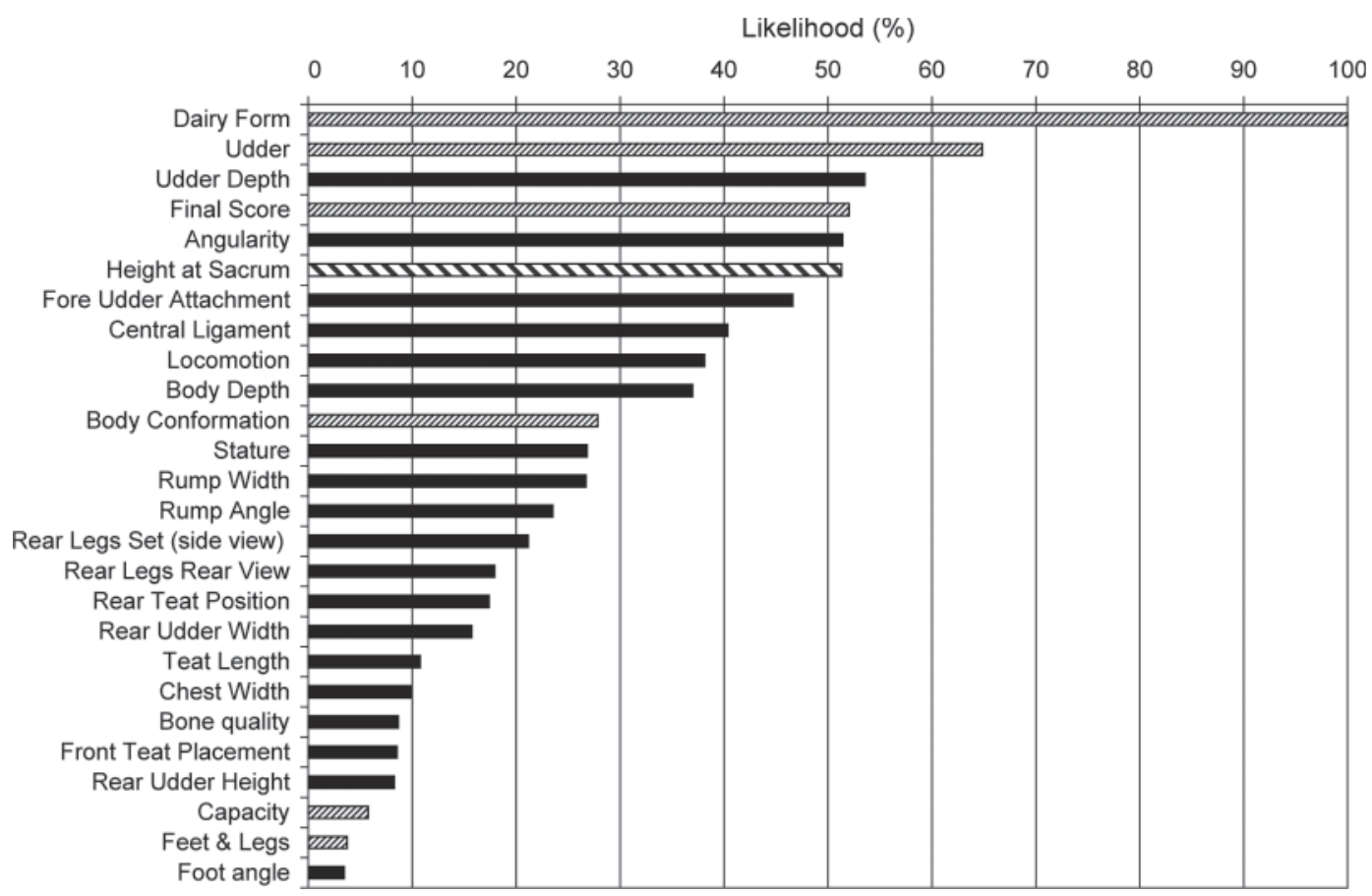

Figure 1. Contribution of the linear type traits, the composite traits, and height at sacrum to the likelihood for functional survival (as a percentage of the contribution of the most important traits) (black bar $=$ linear type traits, slashed bar $=$ composite traits, bold slashed bar $=$ trait measured in $\mathrm{cm}$ ). 
Sewalem et al. (2004). For linear type traits, Schneider et al. (2003) found the highest contribution to likelihood for rear udder height, fore udder attachment, and central ligament; Sewalem et al. (2004) for fore and rear udder attachment and udder depth; and Dadpasand et al. (2008) for fore udder attachment, udder depth, and central ligament. Udder depth was an important trait with respect to longevity in Jersey (Caraviello et al., 2003). Similarly to our results, Larroque and Ducrocq (2001) reported that traits related to udder support (central attachment, udder depth) better explained culling risk differences than traits related to teat length and teat placement. In a study by Buenger et al. (2001), the strongest effects were found for udder traits; namely for udder depth, fore udder attachment, central ligament, rear udder height, and teat placement. In our study, teat placement showed only a small contribution to functional longevity.

A strong relationship between angularity and functional longevity was reported by Dadpasand et al. (2008) in Iranian Holsteins, by Sewalem et al. (2004) in Canadian Holsteins, and by Caraviello et al. (2004) in US Holsteins.

Schneider et al. (2003) reported a moderately high effect of stature, whereas Sewalem et al. (2004) and Dadpasand et al. (2008) found minimal influences for stature and size on longevity. It is interesting that height at sacrum as a measured trait exerted a strong contribution to survival likelihood but stature, a linear type trait, showed only a medium effect on likelihood in our analysis.

Schneider et al. (2003) and Sewalem et al. (2004) found a moderately high contribution of foot angle and bone quality to longevity, whereas we found only a minor effect of foot angle on cow survival. Likewise, Larroque and Ducrocq (2001) found only a small significant effect of rear legs set (side view) and foot angle. In our study, only foot angle showed a small effect on longevity. On the contrary, Buenger et al. (2001) reported that foot angle had a moderate significant effect on functional longevity.

\section{Composite Traits}

Figure 2 shows the RRC for the 6 composite traits. For each of them, the reference level (highest number of records) is class good (75-79 points), which seemed to be optimal with respect to longevity for all traits except final score, udder, and dairy form. The optimum for final score and udder was for class good plus (80-84 points). Cows with the highest classification score (very good, 85-89 points) were more likely to be culled than cows classified with reference level good. A clear trend was observed only for dairy form, where cows with very good classification were the worst with respect to survival and cows classified as poor had the highest survival. The longevity of cows with low classification classes fair and good was impaired for all composite traits except dairy form. The expected improvement of longevity due to higher class for the composite traits was not confirmed. Classes higher than the reference class resulted only in slight improvement or slight impairment of longevity. It seems plausible that Czech Holstein cows highly rated for composite traits have no advantage in functional longevity.

Similarly to our results, Sewalem et al. (2004) found a clear linear relationship between final score and longevity where cows with extremely low final score had the highest risk of being culled, whereas cows classified as excellent had the lowest RRC. Similar results were reported by Sewalem et al. (2004) for mammary system. Our results for final score and udder, as composite traits, correspond to their findings, except for cows in with the highest classification score.

The trend in RRC for dairy form reported by Sewalem et al. (2004) was opposite to our findings, whereas results by Sewalem et al. (2004) for capacity and feet \& legs are roughly consistent with our study.

The negative relationship between dairy form and functional longevity in our study might be attributable to greater management stress in the Czech Holstein population, similar to the situation described by Buenger et al. (2001). They noted that, after correction for milk production, survival was greater for cows with intermediate or low scores for dairy form, which could be a reflection of greater stress of production or poorer body condition among cows with high dairy form.

\section{Linear Type Traits}

Body and Dairy Character Traits. The RRC according to classification scores for angularity and BCS are displayed in Table 2. Similar to the results for dairy form, a clear trend was observed in risk of culling associated with angularity. Angular cows tended to have poorer longevity, whereas less angular cows seemed to be favored with respect to survival. On the contrary, Sewalem et al. (2004) reported the opposite linear relationship between angularity and longevity, favoring angular cows. Buenger et al. (2001) and Caraviello et al. (2004) did not find a linear relationship between angularity and longevity, especially with respect to functional survival. We speculate that our findings as to the relationship between angularity and functional longevity are attributable to involuntary culling in the population, whereas Sewalem et al. (2004) attributed differences among studies to differences in trait definition across countries. 


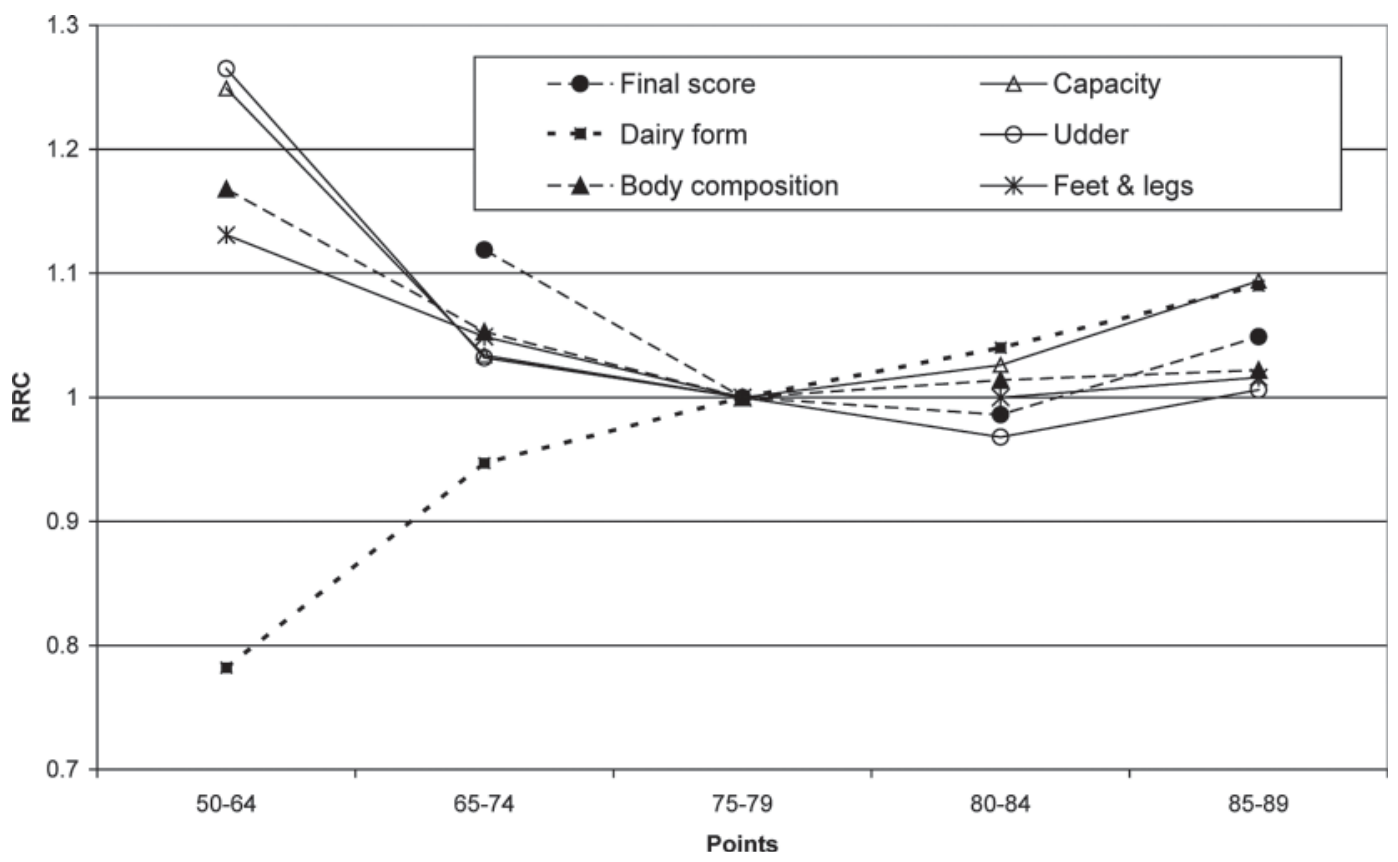

Figure 2. Relative risk of culling $(\mathrm{RRC})$ for composite traits. Classes: 85-89 points $=$ very good; 80-84 points $=$ good plus; $75-79$ points $=$ good, reference level; $65-74$ points $=$ fair; 50-64 points $=$ poor. For final score, combined class fair + poor $=50-74$ points was analyzed.

Classes for BCS also showed a clear trend in risk of culling, especially for functional longevity: survival declined with reduced BCS. If we take into account the relationship between BCS and actual longevity (not corrected on milk production), extreme scores of BCS showed higher RRC than for functional longevity. The optimum RRC occurred at scores 5 and 6 , for which cows probably were healthy, in good condition, and with good milk production. The reduced actual survival for both thin (BCS class 1) and fat (BCS class 9) cows is probably associated with voluntary culling for poor milk production, because cows with poor body condition, as well as fat cows, are likely to be poor milk producers. It is not known whether cows with poor BCS tended toward extreme angularity, with high scores for dairy form. Our results suggest that intermediate BCS (not fat, not thin) is associated with good survival, in particular functional survival.

When BCS and angularity were considered together in the model, angularity showed no significant effect on functional longevity. The RRC were almost the same for scores 1 to 7; longevity was impaired only for scores 8 and 9. E. Němcová (Institute of Animal Science, Prague, Czech Republic, personal communi-

Table 2. Relative risk of culling for angularity, BCS, and rump angle and width

\begin{tabular}{|c|c|c|c|c|c|c|}
\hline \multirow[b]{2}{*}{ Class } & \multicolumn{2}{|c|}{ Angularity } & \multicolumn{2}{|c|}{$\mathrm{BCS}$} & \multicolumn{2}{|c|}{ Rump trait } \\
\hline & No BCS & $\begin{array}{c}\text { BCS in } \\
\text { model }\end{array}$ & $\begin{array}{c}\text { Functional } \\
\text { longevity }\end{array}$ & $\begin{array}{c}\text { Real } \\
\text { longevity }\end{array}$ & $\begin{array}{l}\text { Rump } \\
\text { angle }\end{array}$ & $\begin{array}{l}\text { Rump } \\
\text { width }\end{array}$ \\
\hline 1 & 0.762 & 0.949 & $1.428^{* * 1}$ & $1.847^{* * 1}$ & $1.095^{* * 1}$ & 1.032 \\
\hline 2 & $0.881^{*}$ & 1.016 & & & & 0.944 \\
\hline 3 & $0.913^{* *}$ & 0.991 & $1.139^{* *}$ & $1.300^{* *}$ & $1.092^{* *}$ & $0.917^{* *}$ \\
\hline 4 & $0.904^{* *}$ & 0.960 & $1^{2}$ & $1^{2}$ & 1.015 & $0.932^{* *}$ \\
\hline 5 & $0.961^{* *}$ & $0.962^{*}$ & $0.944^{* *}$ & $0.902^{* *}$ & $1^{2}$ & 0.978 \\
\hline 6 & $1^{2}$ & $1^{2}$ & $0.873^{* *}$ & $0.892^{* *}$ & $1.038^{* *}$ & $1^{2}$ \\
\hline 7 & 1.024 & 1.007 & $0.804^{* *}$ & $0.956^{* *}$ & $1.013^{* *}$ & 1.022 \\
\hline 8 & $1.087^{* *}$ & $1.147^{* *}$ & $0.763^{* * 3}$ & $1.131^{* * 3}$ & $1.084^{* *}$ & $1.048^{* *}$ \\
\hline 9 & 1.108 & 1.012 & & & $1.178^{* *}$ & $1.084^{*}$ \\
\hline
\end{tabular}


cation, 2010) reported that genetic and phenotypic correlations between angularity and BCS were -0.81 and -0.35 , respectively, in the Czech Holstein population. In our data, the phenotypic correlation between BCS and angularity was -0.37 (Němcová, Institute of Animal Science, Prague, Czech Republic, personal communication, 2010). Our results showed that when BCS was included in the model (all cows were adjusted to the same BCS), the most angular cows tended to have poorer longevity, whereas no other score was associated with a substantial advantage in functional survival (see Table 3). It seems that refined, high-angularity Holstein cows are more vulnerable to disease or more sensitive to environmental conditions, which lead to a shorter herd life, independent of effects of their body condition. The results for angularity are consistent with results for dairy form and probably arise for the same reasons. However, results for dairy form (not presented) did not show the same relationship to BCS as did those for angularity.

Relative risk ratios for body traits are shown in Table 3. A clear trend was observed for stature and height at sacrum $(\mathrm{cm})$ : tall cows tended to have poorer longevity. Impaired longevity was also observed for very short animals (score 1 for stature) but RRC was not significant. Longevity was highest for cows with chest width score 4 . The longevity of cows with scores below 4 (narrow chest) was impaired slightly more than the impairment for cows with higher scores (wide chest). Body depth had slightly larger effects on longevity than chest width. Scores 4 and 5 seemed to be optimal with respect to survival. Longevity decreased significantly only for cows with high scores (i.e., deep body). Similar trends for body depth were reported by Caraviello et al. (2004) and Sewalem et al. (2004). Schneider et al. (2003) found that tall and large cows had greater chances of surviving than short and small cows in Canadian Holsteins. Sewalem et al. (2004) also reported a higher risk of culling for cows that were short, small, and narrow, but higher RRC was found for extremely small as well as extremely large cows. Variation in results among experiments could be attributable to differences in voluntary culling strategies in different Holstein populations.

Rump Traits. The relationship between survival and rump trait scores is shown in Table 2. Neither trait had a strong effect on functional longevity, as expected based on previous studies (Larroque and Ducrocq, 2001; Caraviello et al., 2003, 2004). Scores 4 and 5 for rump angle were associated with the lowest risk of culling, indicating an intermediate optimum for this trait, as was also reported by Schneider et al. (2003) and Sewalem et al. (2004). Results for rump width showed that cows with narrower rumps tended to have better longevity, and scores 3 and 4 seemed to be optimal. Longevity of cows with extremely narrow rumps (score 1) was impaired, but that of cows with high scores $(8$, 9) was reduced significantly. Buenger et al. (2001) reported detrimental effects on longevity only for cows with extremely wide rump. Schneider et al. (2003) and Sewalem et al. (2004) reported impaired longevity for extremely narrow rump. Dadpasand et al. (2008) found increased risk of culling for cows with narrow and short rumps. We speculate that the high RRC for wide rump cows might be associated with the high culling risk of tall and broad cows in the analyzed population. The wide rump as a purported advantage with respect to calving ease and cow survival did not assert itself in our data.

Foot and Leg Traits. Relative risk estimates for foot and leg traits are shown in Table 4. Rear legs rear view clearly displayed an intermediate optimum, with lowest risk ratio corresponding to scores 4,5 , and 6 . Longevity of cows with lower scores (severe toe-out) was impaired more than that of cows with high scores (straight legs). In contrast to our results, Caraviello et

Table 3. Relative risk of culling for stature, height at sacrum (level shown, cm), chest width, and body depth

\begin{tabular}{lllllc}
\hline Class & Stature & $\begin{array}{l}\text { Chest } \\
\text { width }\end{array}$ & $\begin{array}{c}\text { Body } \\
\text { depth }\end{array}$ & $\begin{array}{c}\text { Level } \\
(\mathrm{cm})\end{array}$ & $\begin{array}{c}\text { Height } \\
\text { at sacrum }\end{array}$ \\
\hline 1 & 1.093 & 1.072 & $1.073^{1}$ & $120-134$ & 0.981 \\
2 & 0.958 & 1.083 & & $135-139$ & $0.941^{* *}$ \\
3 & $0.951^{*}$ & $1.049^{*}$ & 1.005 & $140-144$ & $1^{2}$ \\
4 & $0.938^{* *}$ & 0.987 & 0.977 & $145-149$ & $1.025^{* *}$ \\
5 & $0.967^{* *}$ & $1.029^{*}$ & 0.988 & $150-154$ & $1.077^{* *}$ \\
6 & $1^{2}$ & $1^{2}$ & $1^{2}$ & $\geq 155$ & $1.190^{* *}$ \\
7 & 1.009 & 1.009 & $1.033^{* *}$ & & \\
8 & $1.061^{* *}$ & $1.042^{*}$ & $1.075^{* *}$ & & \\
9 & $1.111^{* *}$ & 1.023 & $1.180^{*}$ & & \\
\hline
\end{tabular}

${ }^{1}$ Combined class for score 1 and 2 .

${ }^{2}$ Reference level.

${ }^{*} P<0.05 ;{ }^{* *} P<0.01$. 
Table 4. Relative risk of culling for foot and leg traits

\begin{tabular}{|c|c|c|c|c|c|}
\hline Class & $\begin{array}{l}\text { Rear legs } \\
\text { rear view }\end{array}$ & $\begin{array}{c}\text { Rear legs set } \\
\text { (side view) }\end{array}$ & $\begin{array}{l}\text { Foot } \\
\text { angle }\end{array}$ & $\begin{array}{l}\text { Bone } \\
\text { quality }\end{array}$ & Locomotion \\
\hline 1 & $1.215^{* *}$ & 1.115 & $1.025^{1}$ & $0.978^{1}$ & $1.148^{*}$ \\
\hline 2 & $1.118^{* *}$ & 1.001 & & & $1.223^{* *}$ \\
\hline 3 & $1.044^{* *}$ & $0.943^{* *}$ & $1.068^{* *}$ & 0.995 & $1.055^{* *}$ \\
\hline 4 & $1^{2}$ & 0.978 & 1.015 & 1.017 & 1.016 \\
\hline 5 & 1.014 & 0.980 & $1^{2}$ & 1.009 & $1^{2}$ \\
\hline 6 & 1.008 & $1^{2}$ & 1.003 & $1^{2}$ & 1.011 \\
\hline 7 & $1.039^{* *}$ & 1.022 & 1.005 & 1.014 & 1.020 \\
\hline 8 & $1.035^{*}$ & $1.052^{*}$ & $1.014^{3}$ & 0.999 & $1.072^{* *}$ \\
\hline 9 & $1.107^{*}$ & $1.179^{* *}$ & & 0.996 & 1.006 \\
\hline
\end{tabular}

${ }^{1}$ Combined class for score 1 and 2 .

${ }^{2}$ Reference level.

${ }^{3}$ Combined class for score 8 and 9 .

${ }^{*} P<0.05 ;{ }^{* *} P<0.01$.

al. (2004) and Sewalem et al. (2004) found straighter rear legs optimal. For rear legs set (side view), optimal scores ranged from 2 to 7 , with the lowest risk ratio for score 3. Longevity of cows with extremely straight rear legs (i.e., score 1, straight legs) was slightly impaired, and that of cows with sickled rear legs (score 8 or 9) was reduced significantly. Similarly, Buenger et al. (2001), Schneider et al. (2003), Caraviello et al. (2004), and Sewalem et al. (2004) identified sickled legs as detrimental and associated with substantially higher risk of culling. The effect of foot angle on culling risk was minimal. A low effect of foot angle on survival was also reported by Dadpasand et al. (2008); cows with low foot angle tended to have poorer longevity but this trend was slight. Schneider et al. (2003) and Sewalem et al. (2004) also reported that cows with a low foot had more risk of being culled than cows with a steeper foot. In our study, almost no effect with respect to survival was found for bone quality. On the contrary, Schneider et al. (2003) and Sewalem et al. (2004) found impaired survival for cows with coarse bones. A clear trend was observed for locomotion. Optimal scores with respect to longevity ranged from 4 to 9 , with the exception of score 8 , for which a statistically significant risk ratio estimate $>1$ was found. Low scores (corresponding to severely impaired locomotion) led to higher risk of culling. Locomotion seems to be a trait for which any score above a certain threshold is satisfactory, such that only animals with scores below that threshold have impaired longevity (Larroque and Ducrocq, 2001).

Udder Traits. Estimated risk ratios for udder traits are shown in Table 5. As expected based on previous studies (Short and Lawlor, 1992; Larroque and Ducrocq, 2001; Vollema et al., 2000; Caraviello et al., 2004), udder depth was the most important trait with respect to functional longevity. Significantly impaired survival occurred for scores 5 and lower. Cows with higher scores; that is, cows with udders high above the floor, were at lower risk of culling but, in contrast to risk ratios for lower scores, the estimates were nonsignificant. Sewalem et al. (2004) and Dadpasand et al. (2008) reported an intermediate optimum for udder depth with respect to functional longevity, but Caraviello et al. (2004) found a linear relationship between udder depth and functional longevity in Holsteins.

As in almost all previous studies (Short and Lawlor, 1992; Larroque and Ducrocq, 2001; Sewalem et al., 2004), low scores for fore udder attachment were associated with high culling risk. Rear udder height and rear udder width showed intermediate optima, with respect to survival. Central ligament was also an important predictor of survival. Cows with weak central ligament (low scores) had higher risk ratio than cows with strong central ligament (high scores). As for udder depth, significant estimates of risk ratio were found only for score 5 and lower. Optimal central ligament was found for score 6, the reference level. For central ligament, we concluded that high scores did not confer greater longevity but that low scores were associated with significant impairment of survival. Caraviello et al. (2004) reported the same trend in RRC for central ligament. Schneider et al. (2003) and Sewalem et al. (2004) found the same results for rear udder attachment, fore udder attachment, and central ligament. They concluded that cows with strongly attached udders had greater chance of surviving than cows with weak ligaments.

Pursuant to our results as well as published results, we conclude that the most significant effects on functional longevity are generally due to udder traits. Udder traits have an important influence on involuntary culling decisions, mainly because of their influence on susceptibility to injuries and mastitis infection. Further relationships between type traits connected with udders and functional longevity may result from strong 
Table 5. Relative risk of culling for udder traits

\begin{tabular}{lccccc}
\hline Class & $\begin{array}{c}\text { Fore udder } \\
\text { attachment }\end{array}$ & $\begin{array}{c}\text { Rear udder } \\
\text { height }\end{array}$ & $\begin{array}{c}\text { Rear udder } \\
\text { width }\end{array}$ & $\begin{array}{c}\text { Udder } \\
\text { depth }\end{array}$ & $\begin{array}{c}\text { Central } \\
\text { ligament }\end{array}$ \\
\hline 1 & $1.364^{* *}$ & 1.084 & $1.042^{1}$ & $1.417^{* *}$ & $1.309^{*}$ \\
2 & $1.130^{* *}$ & 1.026 & & $1.278^{* *}$ & $1.158^{* *}$ \\
3 & 1.028 & 0.998 & 1.009 & $1.160^{* *}$ & $1.125^{* *}$ \\
4 & 1.016 & 0.977 & 0.991 & $1.084^{* *}$ & $1.044^{* *}$ \\
5 & $1^{2}$ & $1^{2}$ & 1.003 & $1.048^{* *}$ & $1.041^{* *}$ \\
6 & $0.965^{* *}$ & 0.986 & $1^{2}$ & 1.019 & $1^{2}$ \\
7 & 0.975 & 0.997 & $1.042^{* *}$ & $1^{2}$ & 1.024 \\
8 & 0.983 & $1.036^{*}$ & $1.099^{* * 3}$ & 1.006 & 1.030 \\
9 & 0.941 & 1.014 & & 0.979 & 1.003 \\
\hline
\end{tabular}

${ }^{1}$ Combined class for score 1 and 2 .

${ }^{2}$ Reference level.

${ }^{3}$ Combined class for score 8 and 9 .

$* P<0.05 ;{ }^{* *} P<0.01$.

voluntary culling by farmers who do not want cows with "bad" udders, even if no functional deficiency is connected with certain undesired states.

Teat Traits. Results for teat traits are shown in Table 6. Neither teat trait had a strong effect on functional longevity. Teat length showed an intermediate optimum, in the range from score 3 to 7 . Extremely short (scores 1,2) as well as extremely long (scores 8, 9 ) teats were detrimental with respect to survival. An intermediate optimum for teat length was also found by Sewalem et al. (2004).

Front teat placement influenced functional longevity considerably less than rear teat position. Both traits showed intermediate optima. For rear teat position, the low scores (wide position) and high scores (near position) were associated with significant reductions in functional longevity. Scores ranging from 4 to 7 were optimal. Low scores for front teat placement or rear teat position (wide placement) were associated with slightly higher RRC than high scores (close position), which was also reported by Buenger et al. (2001), Larroque and Ducrocq, (2001), Schneider et al. (2003), Caraviello et al. (2004), and Sewalem et al. (2004). Caraviello et al. (2004) and Sewalem et al. (2004) found intermediate optima for both teat placement traits.

\section{CONCLUSIONS}

Survival analysis methodology was used to describe relationships between type traits and functional longevity in the Czech Holstein population. Results were generally consistent with those from studies of other Holstein populations in other countries. Important influences of udder traits, final score, and feet and legs on functional longevity were confirmed. Among the linear type traits, udder depth, fore udder attachment, and central ligament were most important, with a strong relationship with functional survival of cows. A difference among studies occurred in the effects of stature and cow size, possibly because, in contrast to the Canadian Holstein population, smaller cows are preferred in the Czech Republic. A second important discrepancy was found for the association between functional longevity and both dairy form (as a composite trait) and angularity. Both of these traits are meant to describe a body conformation that promotes or predicts high and sus-

Table 6. Relative risk of culling for teat traits

\begin{tabular}{llcc}
\hline Class & $\begin{array}{c}\text { Teat } \\
\text { length }\end{array}$ & $\begin{array}{c}\text { Front teat } \\
\text { placement }\end{array}$ & $\begin{array}{c}\text { Rear teat } \\
\text { position }\end{array}$ \\
\hline 1 & 1.118 & $1.101^{* *}$ & $1.097^{*}$ \\
2 & $1.094^{* *}$ & 1.045 & $1.084^{*}$ \\
3 & 1.001 & 1.015 & $1.077^{* *}$ \\
4 & 0.984 & 0.987 & 1.011 \\
5 & $1^{1}$ & $1^{1}$ & 0.984 \\
6 & 0.989 & 1.013 & 1.019 \\
7 & 0.982 & 1.017 & $1.057^{* *}$ \\
8 & $1.082^{*}$ & $1.03^{2}$ & $1.073^{*}$ \\
9 & $1.178^{*}$ & & \\
${ }^{1}$ Reference level. & & & \\
${ }^{2}$ Combined class for score 8 and 9. & & \\
${ }^{*} P<0.05 ; * * P<0.01$. & & &
\end{tabular}


tainable milk yield with respect to ability and condition to dairy production. It seems that in Czech Holsteins, angular cows and cows with high dairy form are disadvantaged with regard to longevity. The reasons consist probably in management and environmental conditions more appropriate to a dual-purpose breed than to a specialized dairy breed. At the same time, BCS was found to be very important with respect to survival, in agreement with our preceding statement that the Czech management environment might be more suitable to the demands of dual-purpose cattle. Information provided in this study can be used to create specific selection indices that would reflect the optimal conformation of dairy cows in terms of functional longevity. In the selection index for functional longevity, information could be used on longevity of daughters, on udder traits, final scores, and feet and legs traits but it is necessary to take into account the linearity of the relationship between longevity and type traits. From the point of linearity, dairy form, udder, udder depth, fore udder attachment, central ligament, and locomotion appear more suitable. Future studies should focus on estimation of relationship between longevity and fertility traits using survival analysis methodology, as well as investigation of including fertility traits into selection programs for improvement of longevity.

\section{ACKNOWLEDGMENTS}

The authors thank J. Wolf, Institute of Animal Science (Prague, Czech Republic) for helpful comments. Special thanks are extended to W. D. Hohenboken (Corvallis, OR), who edited the English of the paper. Research was supported by the Ministry of Agriculture of the Czech Republic (Projects No. QH 71275).

\section{REFERENCES}

Buenger, A., V. Ducrocq, and H. H. Swalve. 2001. Analysis of survival in dairy cows with supplementary data on type scores and housing systems from a region of Northwest Germany. J. Dairy Sci. 84:1531-1541.

Caraviello, D. Z., K. A. Weigel, and D. Gianola. 2003. Analysis of the relationship between type traits, inbreeding, and functional survival in Jersey cattle using a Weibull proportional hazards model. J. Dairy Sci. 86:2984-2989.
Caraviello, D. Z., K. A. Weigel, and D. Gianola. 2004. Analysis of the relationship between type traits and functional survival in US Holstein cattle using a Weibull proportional hazards model. J. Dairy Sci. $87: 2677-2686$

Dadpasand, M., S. R. Miraei-Ashtiani, M. Moradi Shahrebabak, and R. Vaez Torshizi. 2008. Impact of conformation traits on functional longevity of Holstein cattle of Iran assessed by a Weibull proportional hazards model. Livest. Sci. 118:204-211.

Ducrocq, V. 1987. An analysis of length of productive life in dairy cattle. PhD Diss. Cornell Univ., Ithaca, NY.

Ducrocq. V. 1997. Survival analysis, a statistical tool for longevity data. Proc. 48th Annual Meeting of EAAP, Vienna, Austria. EAAP, Rome, Italy.

Ducrocq, V., and J. Sölkner. 1998. The survival kit-V3.0: A Fortran package for the analyses of survival data. Proc. 6th World Congr. Genet. Appl. Livest. Prod., Armidale, Australia. 27:447-448.

Holstein Cattle Breeders Association of the Czech Republic. 2010. Linear scoring of type traits in Czech Republic - Composite Traits. Accessed Mar. 25, 2010. http://www.holstein.cz/index.php/system-a-vyvoj-hodnoceni-exterieru-v-r/Souhrnne-charakteristiky.

Larroque, H., and V. Ducrocq. 2001. Relationships between type and longevity in the Holstein breed. Genet. Sel. Evol. 33:39-59.

Meyer, K., S. Brotherstone, M. R. Edwards, and W. G. Hill. 1987. Inheritance of linear type traits in dairy cattle and correlations with milk production. Anim. Prod. 44:1-10.

Plemdat. 2010. Description of model for estimations of breeding values for longevity. Accessed Jan. 10, 2010. http://iserv.plemdat.cz/ store/Longevity.pdf.

Schaeffer, G. B., W. E. Vinson, R. E. Pearson, and R. G. Long. 1985. Genetic and phenotypic relationships among type traits scored linearly in Holsteins. J. Dairy Sci. 68:2984-2988.

Schneider, M. P., J. W. Dürr, R. I. Cue, and H. G. Monardes. 2003. Impact of type traits on functional herd life of Quebec Holsteins assessed by survival analysis. J. Dairy Sci. 86:4083-4089.

Sewalem, A., G. J. Kistemaker, F. Miglior, and B. J. Van Doormaal. 2004. Analysis of the relationship between type traits and functional survival in Canadian Holsteins using a Weibull proportional hazards model. J. Dairy Sci. 87:3938-3946.

Short, T. H., and T. J. Lawlor. 1992. Genetic parameters of conformation traits, milk yield and herd life in Holsteins. J. Dairy Sci. 75:1987-1998.

Smith, S. P., and R. L. Quaas. 1984. Productive life span of bull progeny groups: Failure time analysis. J. Dairy Sci. 67:2999-3007.

Vollema, A. R., and A. B. F. Groen. 1997. Genetic correlations between longevity and conformation traits in an upgrading dairy cattle population. J. Dairy Sci. 80:3006-3014.

Vollema, A. R., S. Van Der Beek, A. G. F. Harbers, and G. De Jong. 2000. Genetic evaluation for longevity of Dutch dairy bulls. J. Dairy Sci. 83:2629-2639.

Vukasinovic, N., Y. Schleppi, and N. Kunzi. 2002. Using conformation traits to improve reliability of genetic evaluation for herd life based on survival analysis. J. Dairy Sci. 85:1556-1562.

Weigel, K. A., T. J. Lawlor, P. M. Vanraden, and G. R. Wiggans. 1998. Use of linear type and production data to supplement early predicted transmitting abilities for productive life. J. Dairy Sci. 81:2040-2044

Wiggans, G. R., N. Gengler, and J. R. Wright. 2004. Type trait covariance components for five dairy breeds. J. Dairy Sci. 87:2324-2330 